\title{
Changing Pattern Of Prostitution: An Assessment Of Transnational Commercial Sex Work By Nigerian Women
}

\author{
Bello Ibrahim PhD \\ Sociology Department, Bayero University Kano, Kano State, Nigeria \\ Jamilu Ibrahim Mukhtar \\ Sociology Department, Federal University Dutse, Jigawa State, Nigeria
}

doi: 10.19044/esj.2016.v12n2p81 URL:http://dx.doi.org/10.19044/esj.2016.v12n2p81

\begin{abstract}
This paper is aimed at analyzing the changing pattern of prostitution. However, the definition of the act of prostitution has been metamorphosing for centuries from acceptable to illegal and then (in some jurisdictions) to criminal again, agitations by advocates have also necessitated the nomenclatural alteration from "prostitution" to "commercial sex work". The paper examined how development in information and communication technology allows commercial sex workers to make connections with clients through internet and sell sex on this platform. Globalization processes has also changed the pattern of this business to a transnational activity. Although there are many willing transnational commercial sex workers, but organized criminal syndicates are using this development to traffic some women and children with the false promises of getting a lucrative from overseas but ultimately subject them to sex exploitation, child prostitution and sex labor. As is the plight of some Nigerian women in Italy and other European, Middle Eastern and Asian countries, many women from developing countries are recruited into this institution through human trafficking. As a result of commercial sex many women and girls suffer sexual violence, sex exploitation, sexual abuse and contract STDs. To curtail these problems, governments and transnational institutions are therefore urged to develop mechanisms that can tackle these problems by providing women with decent employment opportunities and increase surveillance across national borders.
\end{abstract}

Keywords: Commercial sex work, human trafficking, prostitution, transnational commercial sex 


\section{Background}

Prostitution as a social phenomenon has been in existence for thousands of years in human history. The earliest record of prostitution appears in ancient Mesopotamia, where priests engaged in sex to promote fertility in the community. All women were required to do temple duty, and passing strangers were expected to make donations to the temple after enjoying its services. Since then, the use of sex for non-sexual ends (Abdullahi, 2009) continued to be transformed. Modern commercial sex has its root in ancient Greece, where Solon established licensed brothels in 500 BCE (Siegel, 2008). Famous men openly went to the prostitutes for the purpose of intellectual, aesthetic, and sexual stimulation. The Greek prostitutes were prevented from marrying because their earnings were used to pay for the temple of Aphrodite. During the middle ages, though prostitution was a sin under canon law it was widely practiced and considered a method of protecting "respectable" women who might otherwise be attacked by young men (Siegel, 2008).

In 1358, the Grand Council of Venice declared that prostitution was "absolutely indispensable to the world." Some church leaders such as St. Thomas Aquinas condoned prostitution; St. Augustine wrote, "If you expel prostitution from society, you will unsettle everything on account of lusts." Nonetheless, prostitution was officially condemned, and working girls were confined to ply their trade in certain areas of the city and required to wear distinctive outfits so they could be easily recognized (Davis \& Farge, 2003; Siegel, 2008). During the period of Reformation, Martin Luther advocated abolishing prostitution on moral grounds, and Lutheran doctrine depicted prostitutes as emissaries of the devil who were sent to destroy the faith. During the early Nineteenth Century, prostitution was tied to the rise of English breweries: saloons controlled by the companies employed prostitutes to attract patrons and encourage them to drink. This relationship was repeated in major U.S. cities, such as Chicago, until breweries were forbidden to own the outlets that distributed their product (Siegel, 2008).

The commercial sex industry has passed through a series of social and legal interpretations from "non-predatory sex crime" (Glaser, 1978), "deviant act” (Clinard \& Meier, 1998), "legally institutionalized enterprise” (Davis \& Farge, 2003), “consensual crime” (Leone-Guerrero, 2005) "organized form of crime" (Holmes, 2007), "victimless crime and public order crime" (Siegel, 2008), to an "illegal sector of informal economy" (Flanagan, 2010). As its definitions and interpretations metamorphoses, nomenclature of its actors has also been going through a repeated transformations; that is from prostitutes and other derogatory terms, such as 'whores' or 'sluts' to the present one-commercial sex workers. The social and legal backups are possibly the reasons why the commercial sex industry 
has penchant for thriving. Now it is believed to achieve increased vitality (Abdullahi, 2009) and gathers more momentum to a point that, advertisement of sexual objects, in some cases sexually explicit activities, are symbols of civilization, freedom and self-fulfillment.

Irrespective of its legality, prostitution has a number of sociological implications. And while the duty of sociologist is not to decode the normative judgment of outright evil or good of any behavior or culture, which could lead to bias Kothari (2004), it is a moral obligation and professional burden upon the sociologist to assess both potential and practical outcomes of the behavior in question. Prostitution takes place in a variety of forms in the current wave of globalization. From the unification of Western and Eastern Germany, Bretzlaff (2008) studied that, prostitution has been going through a series of dramatic changes. She attributed this trend to some noticeable factors: globalization and expansion of Europe Union (EU) following the collapse of communism in Eastern Europe and former Union of Soviet Socialist Republics (USSR) and the legalization of the prostitution in 2002.

Considering the influence of globalization on the expansion of commercial sex industry as it transcends national borders, today physical movement across borders by (il)legal organized syndicates has become commonplace. This trend bred the term 'transnational prostitution'. As is evident in some developing countries of the world, such as Nigeria, Kenya, Ghana, and Ivory Coast women and girls are trafficked to Europe for sexual purposes (Nnadi, 2013). Most girls are made to prostitute under the guise of sex tourism. Sex tourism according to UNICEF Document (as cited in Jekayinfa, 2015) happens when rich men travel during the holidays from the advanced countries of the world to places like Brazil, the Dominican Republic, and Thailand etc., to have sexual dealings with children of between 13 and 15years.

Tepperman (2006) observes that, Nigeria has a large number of adolescents living and making a living on the streets. This has been attributed to economic factors and exposure to all forms of risks. The result is a spread of prostitution among adolescents with its attendant problems (Bamgbose, 2002, as cited in Tepperman, 2006). From much of literature and researches earlier conducted on prostitution or commercial sex, there has been little attention given to its changing pattern and to relationship between active transnational movement (and non-active, such as human trafficking) and commercial sex, especially in Nigeria. For instance, Nnadi (2013) investigated sex trafficking by Nigerian women but the multiple patterns of transnational sex trade and processes of legalization and criminalization prostitution (which shape its changing pattern) have not been examined in 
the study. Tyoanande \& Samson (2014) also studied the phenomenon and they end up viewing it as a social evil rather its continuing transformation.

In view of the above, this article is designed to assess the changing pattern of prostitution in Nigeria. The trend will be analyzed in both the global and national levels with special emphasis laid on transnational commercial sex by Nigerian women as a parameter. The fact that, the prostitution is one of the global reported crimes (Kangaspunta, 2003) is enough an impetus for the conduct of the study.

\section{Conceptualization: "Prostitution" as "Commercial Sex"}

As stated in the introductory section, the concept of prostitution had been going through nomenclatural metamorphoses. Under the auspices of sex workers activists, the term prostitution was replaced by the name "commercial sex" and "prostitutes" referred to as "sex workers" towards the end of 1970s. The word prostitution is derived from the Latin word prostituere meaning: pro (up-front) and stituere (offer for sale) (Tyoanande \& Samson, 2014). Therefore, prostitute is someone who publicly offers his or her body for sale.

Siegel (2008) defined prostitution as granting non-marital sexual access, established by mutual agreement of the prostitutes, their clients, and their employers, for remuneration. This definition is gender-neutral because prostitutes can be straight or gay and male or female. Prostitutes are referred to by sociologists as "street-level sex workers" whose activities are similar to any other service industry. Prostitution occurs in a variety of ways, such as full time prostitution; some engage in legitimate business in the day time and go into prostitution at night while some indulge in it as an auxiliary service (Tyoanande \& Samson, 2014).

The pattern of commercial sex work is rapidly changing over the years. While sex tourism generates revenue to developing countries that host tourists, such as Thailand, it also provides great financial profits to the sex workers. Sex services are not only offered in brothels or in city streets, but there are now sex clubs, internet sex and other transnational sex businesses (Siegel \& Senna, 2004). Thus, prostitution or commercial sex has become embedded in organized crime.

\section{Theoretical explanation}

Two theories: Differential Association theory by Edwin Sutherland (1947, as cited in Croall, 2010) and Social Exchange theory by George Homans (1961, as cited in Ritzer, 2011) would be used to explain the institution of prostitution or commercial sex industry. However both theories are explaining at micro-levels of social analysis, they can contribute in 
understanding why some Nigerian women in particular and all prostitutes world over joined the sex trade as a source of living.

In his widely celebrated Differential Association theory, Sutherland (1947) advanced one of the best known sociological explanations of deviance and crime. The theory is built based on the proposition that, like conformity, criminal behavior is learned in the course of interaction with others; most people come into contact with those individuals who think that laws can be broken. In other words, the principle of differential association states that, a person becomes criminal because of a stronger exposure to law breakers than law abiding others. This is likely to be qualitative rather than quantitative.

The theory of differential association is based on two key notes; learning takes place within intimate personal groups and the content of what is leaned include not only techniques for committing crimes, but also motivates attitudes and rationalization. In trying to understand why Nigerian women engage in transnational commercial sex, it is pertinent to caste a cursory look at the priority these girls and their poor families place on means of survival through the material outcome of the business. The duration they take living with professional transnational criminals (acting here as pimps) is also a process of socializing the women in this direction. In addition, the intensity of influence and pressure by the pimps, friends, and other desperate but veteran prostitutes is a reason enough to lead the women into transnational prostitution. In other words, people learn to engage in commercial because of the intensity and duration of socialization and the priority they place on the business and its profit.

Exchange theory, on the other hand, is rooted from Rational Choice approach, which sees human behavior being guided by hedonistic principle or pleasure-seeking. The leading figure in Exchange theory is Homans (1961). Homan's main interest was on the history of rewards and costs, which lead people to do what they do. Basically, Homans argued, people continue to do what they have found to be rewarding in the past. Conversely, they cease doing what has proved to be costly in the past. To understand behavior, we need to understand an individual's history of rewards and costs.

Because of the reciprocal nature of sexuality, sex is always a form of trading. Thus, using Exchange Theory, commercial sex work and receiving a return for offering sex can be explained in terms of give and take. It involves give and take because the commercial sex workers receive money from client before or after offering the sexual service. That is the reciprocal aspect of the industry. From a broader perspective, sex is also an instrument of social exchange that brings certain desired and desirable aspects to intimate relationships, too. Sexual interaction can be viewed thus through the perspective of social exchange theory or sexual economics. Even in its most 
limited forms, people are trading touching and some degree of sexual pleasure.

For the most part, various feelings and wanting to give pleasure to the partner are also part of the exchange. The exchange is of a different nature if sex is used as an item to trade for some other type of benefit or for actual compensation. This is the case in commercial and paid sex. Pornography is included in this context because of the economic values associated with it. People use money to buy video tapes, adult magazines, VCDs, DVDs, satellite cards or internet data to access pornography.

The social exchange theory presents a view of how the sexual negotiations and actions that occur in relationships are organized and linked together in a social system. In social exchange theory, people's choices are affected by the costs and benefits they entail. In social interaction, everyone gives something and receives something in return. In this kind of exchange, people try to maximize the benefits for themselves. Social interaction is usually maintained only when all parties are getting more out of the deal than they are losing. Often, sexual services are exchanged for other services, such as gifts or money.

The two theories: differential association and exchange are all from the mainstream interactionist perspective, but because of its ability to explain the rational aspect of involvement in commercial sex, the Exchange theory is adopted in this paper. This is because by defining prostitution as an object offered to barter with money or gifts, the theory permits us to transcend the meaning of the phenomenon beyond sex as a selling object, but also (especially in Nigerian context) sex as a dilemma. In other words, most of the Nigerian women resorted to the business due to economic reasons that they disregard their birth pride in exchange for some little penny for sustenance.

\section{Changing Pattern of Prostitution}

Prostitution is one of the oldest businesses in the category of either criminal or social deviance. However, sexual revolution which took place in the United States in the 1960s represented a defining moment in which issues regarding sexuality break away from conventional heterosexual life. This revolution also began to pave way for other eccentric sexual orientations. Yet, it can be argued that, capitalism is the system that nurtures commercial sex industry. As John Rex (1974) points out, in the social ideal of capitalism, everything (goods and services, Godly and ungodly) becomes a commodity including religious salvation or baptism, education, bath soap or child birth, silver or steel, sex and even smile. To worsen the matter, the modern system warrants the concealment and revelation of secrecy for money (Simmel 
1906, as cited in Ritzer, 2011). In this light, Bretzlaff (2008:5) describes the status of sex market during the unification of East and West Germany:

While in the West prostitution was (unofficially) tolerated, the selling of sex in the GDR [German Democratic Republic] was illegal and regarded as an especially crass form of capitalist exploitation that recognized women as victims of an unjust system. In this view, before mass entry into paid employment women sold their bodies in return for financial security, either in the respectable manner by way of marriage or in the open sex trade.

The system of capitalism internalizes the principle of "get rich quick" and "get rich or die trying" leaving people in the wilderness seeking of monetary fortune by hook or crook. The capitalism invents luxuries as an avenue for enjoying one's the material success. The system also dominates all social structures like the legal institution which defines the legality or otherwise of obscenity for money and censorship. But the contradiction of capitalism is evident even in the proliferation of pornographic sites. Laws against pornography, prostitution, and drugs are believed to be motivated more by moral crusades than by economic values (Siegel, 2008).

In the quest for harnessing the sexual rights of people with disability, the disabled persons are allowed to use sex workers as objects of sexual expressions, some governments and disability organizations have developed new targets and strategies, which aim to improve disabled people's rights to express their sexuality, and some of these go as far as including the use of prostitutes, and sex surrogates (Owens, 2002).

Pornography and other commercial sex works are highly lucrative services to the producers and porn stars. Some of the "service providers" in the Emperor's Club were paid more for a few days' work than a waitress or teacher makes in a year. The highly paid "models" seemed quite willing to ply their trade. In line with the above, Siegel (2008) maintains that, most of organized criminal activities income comes from prostitution, but the way and manner in which this prostitution operate differ from traditional procurement. Transnational human trafficking has taken commercial sex dimension. Eastern Europe has been the scene of a massive buildup in organized crime since the fall of the Soviet Union. Trading in illegal arms, narcotics, pornography, and prostitution, they operate a multibillion-dollar transnational crime cartel.

Because of increasing globalization, customs and traditions of the West are indigenized in other non-Western societies. The percentages of young Muslim girls who are involved in prostitution are increasing in number. And, most of them are Malay Muslims. It is so upsetting to see that 
the young Muslim generations deviating, being easily influenced by the Western lifestyles and cultures displayed through the films and movies. Male prostitutes are now becoming a common trend due to entrenchment of gay and lesbian communities in especially the West.

In the 1970s, an inn catering to gay men, run by a gay male couple, gained visibility and may have had a positive impact on public attitudes in one working-class Vermont town, until it gained notoriety as the alleged site of male prostitution (Bernstein, 2002). When robbing male victims, female arm robbers do pretend to be sex workers as a subtle way to rob the men of their property by using sedative or hallucinogenic substance in drink. Women "set them up" in order to catch them off guard; some feign sexual interest or prostitution to gain the upper hand.

Research on prostitution shows that, many young runaways and abandoned children are coerced into a life on the streets, where they are cruelly treated and held as virtual captives. It has been estimated that women involved in street prostitution are 60 to 100 times more likely to be murdered than the average woman and that most murders are the result of a dispute over money rather than being sexually motivated. Clearly, prostitution carries with it significant professional risk (Siegel, 2008: 426).

Of the estimated 1 billion people living in slums, over half are under the age of 25, and 40\% are estimated to be under the age of 19 (Ajaegbu, 2012). The accelerating level of prostitution, armed robbery, rape and all facets of crime can be largely attributed to the incidence of unemployment (Ajaegbu, 2012). In line with the above, Former Commissioner of the New York Police Department (NYPD), Patrick Murphy (1985, cited in Richerson, 2002) also notes that, criminal tendencies are rooted in numerous causes associated with socioeconomic, psychosocial, and political factors.

Thus, poverty, unemployment, underemployment, racism, poor health care, bad housing, weak schools, mental illness, single-parent families, teenage pregnancy, and a society of selfishness and greed are all reasons behind social deviance, including commercial sex work. The experiences of adolescent prostitutes vary: some are in brothels; some are streetwalkers, call girls, and casual, part-time, or floating prostitutes. Children and youth from disadvantaged families are vulnerable to fall prey to criminal networks. Siegel \& Senna (2004) also note that, one of the most alarming developments has been the involvement of children in the international sex trade. According them, Russia is one of those countries plagued with internet sex rings that include pornographic pictures of youth. Not only in Russia, Siegel \& Senna (2004) observed that, youth global 
prostitution is commonplace in the whole of Europe and Asia. Desperate young girls and boys in war-torn areas such as former Yugoslavia and other impoverished areas of Eastern Europe and Asia have gotten involved with gangs that ship around the world. This makes it pertinent to discuss issues related to human trafficking and transnational prostitution in Nigeria and beyond.

\section{Human Trafficking and Transnational Commercial Sex by Nigerian Women}

It has become a common trend that, women, usually young, are falling into traps of transnational corporate criminal syndicates by agreeing to go to abroad for work as housemaids or to serve as waitress in restaurants outside of their countries but ended in commercial sex. Most foreign prostitutes working in western countries did not know that they would work as prostitutes before coming to the developed world; or that any individual who contributes to the fact that a person travels abroad to work as a prostitute is a trafficker independently of whether the prostitute wants to travel or not (Thorbek \& Pattanaik, 2003). For instance in Netherlands alone, Bruinsma \& Bernaco (2004) accounted that, approximately 25,000 men and women work as prostitutes.

According to statistics, between 10,000 and 20,000 young Nigerian women are engaged in prostitution on streets and forests of Italy. Some of them are forced into this commercial sex activity in the foreign countries (Godano, 2015). The working method in transnational trafficking in women can be roughly divided into three phases (Bruinsma \& Bernasco, 2004): recruitment of women in the country of origin, transportation of women to the destination country and (sale and) sexual exploitation of women in the destination country. Local criminals usually carry out recruitment in the country of origin.

Via personal contacts or advertisements women are given false hope of obtaining a well-paid job in the West. Approximately half the women have already been working as prostitutes in the country of origin (Bruinsma \& Bernasco, 2004). In many cases the women know or suspect that prostitution is involved, but they have a rose-tinted idea of what prostitution is in the West. They are generally not well aware that they will in fact be brutally exploited (Bruinsma \& Bernasco, 2004).

Nnadi (2013) observe that, domestic and international trafficking of Nigerian women and children has been the trend in the last two decades. Presently, there is an obvious and fast evolving trend in the trafficking of Nigerian women and young girls to the United Kingdom to work as domestic servants. It is now a common fact that a huge number of girls claiming asylum in the United Kingdom are, in reality, trafficked persons. It is sad 
those Nigerian women and children that are either trafficked internally or externally are usually trafficked for sex work or services. For Nnadi (2013), this rate of trafficking has been increasing to the extent that, so many Nigerians equate trafficking with prostitution alone and not other forms of labor.

\section{Discussions}

Prostitution has taken new dimensions over the years. Although Henslin (2010) sees 'bonded labor' as the modern slavery, trafficking in persons is another form of modern-day slavery. In the U.S., the government estimates that approximately 50,000 women and children are trafficked every year. International trafficking in women for the sex industry has been a characteristic of modern day transitional organized crime (Abadinsky, 2007). In this description of event, the women and girls-child are exposed to prostitution and, they like it or not, many of them will join the industry. That is why Sutherland (1940) contends that, learning takes place in group: for an individual to move towards conformity or deviance depends on the extent of her contact with others who encourage or discourage conventional behavior, and that is what he meant by 'differential association’ (Macionis, 2009).

Involvement of minors into sex businesses under duress by adults is a flagrant violation of public order, juvenile justice, moral and even criminal codes. For example, because proliferation of child pornography in Russia, more than 800 tapes and videos were seized in Moscow during Operation Blue Orchid (a joint operation conducted by Russian Police and U.S. Customs agents) in May 2001 alone (Siegel \& Senna, 2004). And since children are born innocent (Paranjape, 2012), the roles of children as sex workers or objects of explicit pictures in pornographic sites is said to be result of their associations with pedophiles and owners of child-scouting pimps.

This cuts across Eastern Europe, Western Europe, Latin America, Africa and Asia. Abadinsky (2007) observes that, Italian, Albanian, Russian, Chinese, Japanese criminal groups have been at the center of global trade that enslaves female adults and children for sale or being forced to sex slavery. Balkan people are inherently attractive to travel abroad, and although the women in general are aware of the fact that the offers for certain types of work abroad in reality means prostitution, they tend to go. These women are knowledgeable of that they are going to work as prostitutes consider their present living conditions and income earnings as considerably poorer than the prospects of prostitution outside their countries (Abadinsky, 2007).

The above description of rational choice by Balkan women is the justification of exchange theory in this context. As Homans (1961) notes, 
people tend to be engaging in what they found to be ultimately rewarding. Even Nigerian women that chose to go abroad for pay work had rationalized their present living conditions and lucrative outcome of working outside the country. It is just that both the advertent migrating sex workers and misled ones who thought they are going for another job are usually ending up as victims of criminal syndicates who make money through the pride of these women.

While commercial sex can be legalized in some countries or states, illegitimacy is usually creeping into the processes in the course of running sex markets. However, Bruinsma \& Bernasco (2004) saw the large figures of men and women that sale sex in Netherlands as a trend that can call for legal demand for sexual services, but they admit that, in the case of trafficking in women "we find a legal market, as such, which is partly serviced via illegal activities, where the women are subject to duress, blackmail and deprived of their liberty" (p 84). Some of these prostitutes come to work in the country as a consequence of illegal trafficking in women or through trafficking in minors. These victims of trafficking come from all over the world, Nigeria (13 percent), North Africa (5 percent), Latin America (22 percent), Middle and Eastern Europe (19 percent) and even from the Netherlands itself (32 percent) (Bruinsma \& Bernasco, 2004).

In fact, pattern of prostitution has entire transformed from within and outside Nigeria. There are some young girls in the town now coming from different parts of Nigeria. They look decent during the day, but they begin their sexual markets when it is night time. There are many of these prostitutes who make modern style and methods of selling sex. Some Nigerian prostitutes are now making connections and appointment with potential client using the internet. Some do prostitute through food selling, others through Hausa dramas and following movie stars as well as those that follow politicians.

Be it legal or illegal behavior, prostitution has many negative social and psychological consequences. Like other acts, such as drug use, prostitution erodes the moral fabric of society and therefore should be prohibited and its actor should be sanctioned. In his classic statement on the function of morality in the law, legal scholar Sir Patrick Devlin states:

Without shared ideas on politics, morals, and ethics no society can exist... If men and women try to create a society in which there is no fundamental agreement about good and evil, they will fail; if having based it on common agreement, the agreement goes, [and] the society will disintegrate. For society is not something that is kept together physically; it is held by the invisible bonds of common thought. If the bonds were too far relaxed, the members would drift apart. A common morality is 
part of the bondage. The bondage is part of the price of society; and mankind, which needs society, must pay its price. (quoted in Siegel, 2008:427).

In fact, prostitution is criminal act, as argued by some legal scholars, because it is one of the functions of the criminal law to express the collective feeling of revulsion toward certain acts, even when they are not very dangerous. Perhaps, this is the rationale behind banning of commercial sex work in the streets of the Federal Capital Territory (FCT) Abuja by its Former Minister, Bala Mohammed, in 2010

\section{Conclusion and Recommendations}

In conclusion, prostitution or its alternative terms: 'commercial sex', 'sex work', or 'sex trade' is responding to globalization forces. Just the way legal and morally conforming businesses are moving with goods and services, sex workers are transporting sexual services at transnational level. It is also true that capitalism has turned all services, including sexual service, to a commodity to be offered in exchange for money. This is why some countries legalize prostitution because they generate income through it. However, legality of it has paved way for opportunistic organized criminals. These criminal organizations are transporting women and children from disadvantaged countries with false promises of securing a job in rich countries, such as European countries. Upon arriving at the country of destination, the visas and passports of these women and children are seized and they are subjected to sex slave or sex trade. Although some women are not aware of that going to prostitute, many of them know that they are going for this type of business.

Many Nigerian women, majority of who are from Edo state, have gone to Italy for commercial sex. Among these prostitutes, there are girls of 14,17 , and 18 years of age. And they usually end up regretting their actions. Studies have linked prostitution with many social vices. Not only that Nigerian young women and adult women who venture into transnational prostitution are experiencing serious human rights violation, such as hate crimes, sexual exploitation and violence from their pimps and clients, they are also vulnerable to sexually transmitted diseases. Prostitution also has positive relationship with drug addiction. In general, commercial sex threatens public order and safety. In view of this, it is necessary for governments, nongovernmental organizations and other transnational agencies, community and families to come up with concerted efforts in fighting this trend. Specifically, the following suggestions are recommended to fight transnational commercial sex by Nigerian women:

- Fighting poverty and unemployment among youth and adult populations shall be the priority of a government if attainment of 
security is the primary need of such government. Therefore, in order to curtail all criminal and deviant tendencies, Nigerian government must make jobs available for the teeming Nigerian youth and their adult counterparts. This will directly or indirectly fight the high rate of poverty that bedevils the country and, by implications, reduce the tendency for transnational prostitution by Nigerian women.

- Nigerian government shall also make sure that girls-child education is free and compulsory from elementary to completion of female children's high school. Further studies by females up to tertiary levels should also be encouraged. This will enable the Nigerian women prepare a career development with decent jobs that can provide an alternative to sex industry.

- There is also a dire need for making sure that, Nigerian agencies established with the objective of fighting human trafficking and smuggling in persons, such as National Agency for Prohibition of Traffic in Persons and other related matters (NAPTIP) are operating effectively. The Nigeria Police Force, Nigeria Immigration Service and other law enforcement agencies shall also complement the effort of this agency or even assume its role in its absence.

- Non-governmental organizations and transnational institutions that are vested with the power to fight transnational organized crime, such as United Nations Office on Drugs and Crime (UNODC) shall also intensify surveillance across Nigerian borders. These institutions shall also turn a special attention to the activities of Nigerians in Diaspora. This is because prior to the emergence of Boko Haram terrorism, Nigerian borders were porous that people are immigrating and emigrating through the borders without proper probing. To this day, people can traffic women and children in the guise of pilgrimage, studies abroad, visits, etc. Proper investigation may reduce this menace.

- Community members where potential transnational prostitutes are belonging shall engage in massive community service, vigilantism or neighborhood watch to target potential prostitutes. There are many community treatment centers now established for counseling juvenile and adult offenders or deviants in developed societies. This culture may contribute in reducing the tendency of young women joining prostitution.

- In the communities, religious institution can also play a vital role in calling the attention of young girls who seem to act beyond the 
religious and moral code to be preached using what they have faith in.

- Families of a potential commercial sex worker are the primary givers of socialization. The families shall in the first place train their children to become morally upright and to avoid anything that goes contrary to the conventional norms. This will make the image of the family to remain intact and untarnished in traditional societies, such as Nigeria.

\section{References:}

Abadinsky, H. (2007). Organized Crime (eighth edition). Belmont: Thomson Abdullahi, S. A. (2009). "Sociological Perspectives" in Abdullahi, SA. Mohammed, I. Z., and

Casey, C. (eds). Studies in Cultural Sociology. Ibadan: Foludex Printers.

Ajaegbu, O. O. (2012). Rising Youth Unemployment and Violent Crime in Nigeria. American Journal of Social Issues and Humanities. 2 (5) 315-321.

Bernstein, M. (2002). “The Contradictions of Gay Ethnicity: Forging Identity in Vermont”. In

Mayer, D.S., Whittier, N. and Robnett, B. (eds) (2002) Social Movement: Identity, Culture and the State. Auckland: Oxford University Press.

Bretzlaff, A. (2008). An Examination of Changing Patterns of Prostitution in Germany Since Unification. Carleton University, Canada's Capital University.

Bruinsma, G. \& Bernasco, W. (2004). Criminal Groups and Transnational Illegal Markets. Crime, Law and Social Change. 41: 79-94.

Clinard, M. B. \& Meier, R.F. (1998). Sociology of Deviant Behavior. Philadelphia: Harcourt Brace.

Croall, H. (2010). Understanding White-collar Crime. Buckingham: Open University press.

Davis, N. Z. \& Farge, A. (2003). History of Women in the West. The Renaissance and The Enlightenment Paradoxes. London: Havard University Press.

Flanagan, W.G. (2010). Urban Sociology: Images and Structure. (5 ${ }^{\text {th }}$ Edn). New York: Rowman \& Littlefield Publishers

Glaser, D. (1978). Crime in Our Changing Society. New York: Holt Rhinehart and Winston.

Godano, S. (2015). Shattered Dreams of Nigerian Sex Workers in Italy. Quick News Africa, published on: Sun March $8^{\text {th }} 2015$ http://www.quicknews-africa.net/shattered-sex-workers-in-italy/

Henslin, J. (2010). Sociology: A Down to Earth Approach (10 ${ }^{\text {th }}$ edn.). Boston: Pearson. 
Jekayinfa, A. A. (2015). Types, Causes and Effects of Gender-Based Violence: Challenges for Social Studies Education in Nigeria. (Retrieved from www.google.com on $30^{\text {th }}$ January, 2015).

Kangaspunta, K. (2003). Mapping the Inhuman Trade: Preliminary Findings of the Data Base on Trafficking in Human Beings. Forum on Crime and Society. vol. 3 (1 and 2) December 2003. 81-103.

Kothari, C.R. (2004). Research Methodology. New Delhi: New Age Ltd. Publishing.

Leon-Guerrero, A. (2005). Social Problems: Community, Policy, and Social Action. Thousand Oaks: Pine Forge Press.

Macionis, J.J. (2009). Social Problems ( $3^{\text {rd }}$ edn). New Jersey: Pearson.

Nnadi, I. (2013). Sex Trafficking and Women-The Nigerian Experience. Journal of Politics and Law. Vol.6, No.3. p. 179-188.

Owens, T. (2002). 'TLC: Sexual Services for Disabled People', TLC Trust, Available from: http://www.tlctrust.org.uk/ (Accessed $21^{\text {st }}$ Feb. 2015).

Paranjape, N.V. (2012). Criminology, Penology, and Victimology (Reprinted $15^{\text {th }}$ edn). Allahbad: Central Law Publications.

Rex, J. (1974). Sociology and the Demyistification of the Modern World. London: Routledge.

Richerson, $\mathrm{x}$ (2002). Crime and Criminality. Available online at www.google.com (Accessed on $17^{\text {th }}$ November, 2015).

Ritzer, G. (2011). Sociological Theory ( ${ }^{\text {th }}$ Edition). New York: McGrawHill.

Siegel, L. (2008) Criminology : the Core. Belmont: Wadsworth.

Siegel, L., \& Senna, J. (2004). Essentials of Criminal Justice ( $4^{\text {th }}$ edn) Belmont: Thomson/ Wadsworth.

Tepperman, L. (2006). Deviance, Crime, and Control: Beyond the Straight and Narrow. Ontario:Oxford University Press.

Thorbek, S. \& Pattanaik, B. (eds)(2003). Transnational Prostitution: Changing Patterns in a Global Context. London: Zed Press.

Tyoanande, G.T. \& Samson, A.J. (2014). Prostitution as a Social Evil in Nigeria: Issues and Challenges. International Journal of Peace and Conflict Studies. 2 (1) 29-36. 